\title{
Ocimum sanctum leaf extracts stimulate insulin secretion from perfused pancreas, isolated islets and clonal pancreatic $\beta$-cells
}

\author{
J M A Hannan, L Marenah, L Ali ${ }^{1}$, B Rokeya ${ }^{1}$, P R Flatt \\ and Y H A Abdel-Wahab \\ Diabetes Research Group, School of Biomedical Sciences, University of Ulster, Coleraine, Northern Ireland BT52 1SA, UK \\ ${ }^{1}$ Department of Pharmacology, Biomedical Research Group, BIRDEM, Dhaka-1000, Bangladesh \\ (Requests for offprints should be addressed to Y Abdel-Wahab; Email: y.abdel-wahab@ulster.ac.uk)
}

\begin{abstract}
Ocimum sanctum leaves have previously been reported to reduce blood glucose when administered to rats and humans with diabetes. In the present study, the effects of ethanol extract and five partition fractions of $O$. sanctum leaves were studied on insulin secretion together with an evaluation of their mechanisms of action. The ethanol extract and each of the aqueous, butanol and ethylacetate fractions stimulated insulin secretion from perfused rat pancreas, isolated rat islets and a clonal rat $\beta$-cell line in a concentration-dependent manner. The stimulatory effects of ethanol extract and each of these partition fractions were potentiated by glucose, isobutylmethylxanthine, tolbutamide and a depolarizing concentration of $\mathrm{KCl}$.
\end{abstract}

Inhibition of the secretory effect was observed with diazoxide, verapamil and $\mathrm{Ca}^{2+}$ removal. In contrast, the stimulatory effects of the chloroform and hexane partition fractions were associated with decreased cell viability and were unaltered by diazoxide and verapamil. The ethanol extract and the five fractions increased intracellular $\mathrm{Ca}^{2+}$ in clonal BRIN-BD11 cells, being partly attenuated by the addition of verapamil. These findings indicated that constituents of $O$. sanctum leaf extracts have stimulatory effects on physiological pathways of insulin secretion which may underlie its reported antidiabetic action.

Journal of Endocrinology (2006) 189, 127-136

\section{Introduction}

Diabetes is a serious metabolic disorder with micro- and macrovascular complications that result in significant morbidity and mortality. The aging population, consumption of calorie-rich diets, obesity and sedentary lifestyles have led to a tremendous increase in the number of individuals with type 2 diabetes worldwide. Current drugs used for diabetes therapy are not free from side effects and do not restore normal glucose homeostasis (Rang et al. 1991). Moreover, providing modern medical healthcare across the world, especially in developing countries, is still a far-reaching goal due to economic constraints. Thus, it is necessary to look for new and, if possible, more efficacious drugs and to make use of the vast reserves of phytotherapy for medicinal purposes.

Since time immemorial, individuals with diabetes have been treated orally in folk medicine with a variety of plant extracts. Recently, there has been increasing interest in the use of medicinal plants. The plant kingdom has become a target for multinational drug companies and research institutes for the discovery of new biologically active compounds and potential drugs (Evans 1996). The World Health Organization has recommended, especially in developing countries, the initiation of programmes designed to use medicinal plants more effectively in the traditional healthcare system (World Health Organization 1978). The resolution of the 31st World Health Organization Assembly requested a complete inventory, and a thorough evaluation of the efficacy, safety and standardization of medicinal plants for the treatment of diabetes (Farnsworth 1980).

Ethnobotanical information indicates that more than 800 plants have been used as traditional remedies for the treatment of diabetes (Ajgaonkar 1979, Alarcon-Aguilara et al. 1998). The antihyperglycaemic activity of a large number of these plants has been evaluated and confirmed in different animal models (Karawya et al. 1984, Farjou et al. 1987, Swanston-Flatt et al. 1991a, 1991b, Jouard et al. 2000). In India, a number of plants are mentioned in ancient literature (Ayurveda) for the treatment of diabetes and some of them have been tested experimentally (Chopra et al. 1956, Rajashekharan \& Tuli 1976, Chattopadhyay 1993, 1999, Pugazhenthi \& Murthy 1996, Joy \& Kuttan 1999).

Ocimum sanctum Linn. (Labiatae), commonly known as holy basil, is an herbaceous plant found throughout the south Asian region. The plant grows wild in India, but is 


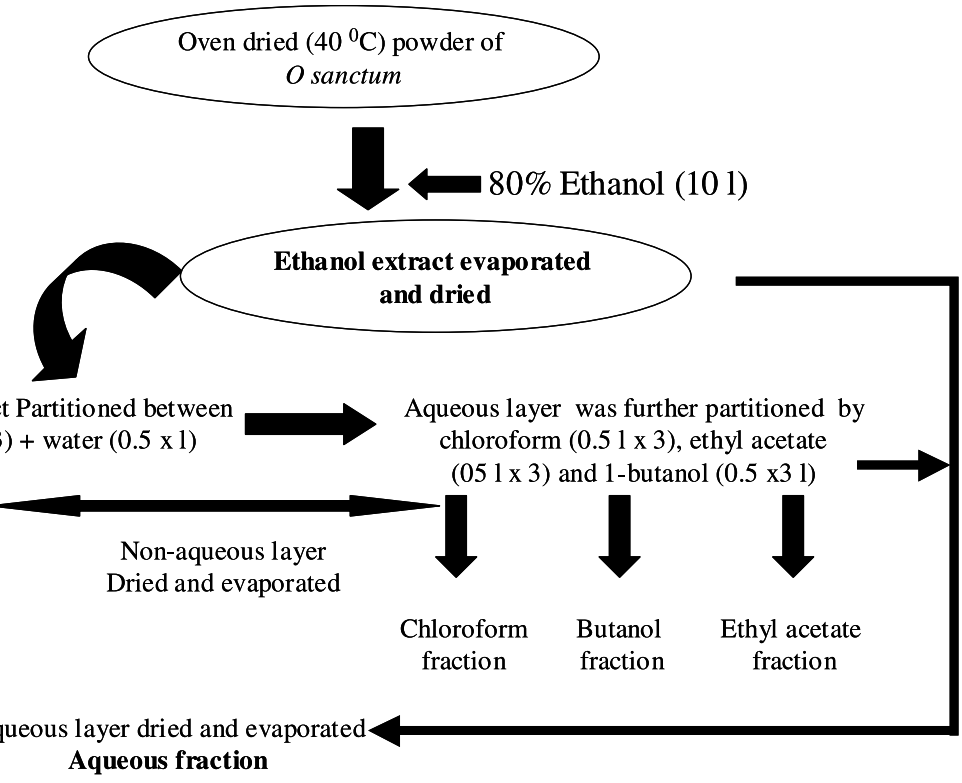

Figure 1 Preparation of ethanol extraction and five partition fractions (hexane, chloroform, butanol, ethylacetate and aqueous) of dried leaves of $O$. sanctum.

also widely cultivated in homes and temple gardens. Apart from religious significance, it has a long history of medicinal use and is mentioned in Charak Samhita, the ancient textbook of Ayurveda. Other texts mention the use of basil leaves for a variety of conditions such as catarrhal bronchitis, bronchial asthma, dysentery, dyspepsia, skin diseases, chronic fever, haemorrhage and helminthiasis, and topically for ring worms (Singh et al. 1980, Kirtikar \& Basu 1993, Wagner \& Winterhoff 1994, Warier 1995a). Fresh leaves taken with black pepper are used as a prophylactic measure for malaria (Dastur 1962). Holy basil has been shown also to be effective as antistress, adaptogenic and attenuates the stress-induced changes (Bhargava \& Singh 1981, Singh et al. 1991a, 1991b).

Leaves of $O$. sanctum have been shown to possess hypoglycaemic effects in experimental animals (Joglekar et al. 1959, Dhar et al. 1968, Chattopadhyay 1993, Rai 1997). The ethanol (70\%) extract of O. sanctum leaves caused a significant reduction of blood glucose in normal, glucose-fed hyperglycaemic and streptozotocin-treated diabetic rats. A diet containing leaf powder (1\%) fed to normal and diabetic rats for 1 month significantly reduced fasting blood glucose (Rai 1997). In a randomized, placebo-controlled, crossover, single blind clinical trial, leaf extract of $O$. sanctum caused a significant decrease in fasting and post-prandial glucose (Agrawal et al. 1996). More recently, an ethanol extract of $O$. sanctum was shown to reduce hyperglycaemia in alloxan diabetic rats in both acute and long-term feeding studies (Vats et al. 2002).

Despite this research, no studies have been performed to assess how the antihyperglycaemic action of $O$. sanctum is mediated. In the present study, an ethanol extract and five partition fractions of $O$. sanctum leaves were evaluated for their effects on insulin secretion using isolated perfused rat pancreas, isolated islets and clonal BRIN-BD11 cells.

\section{Materials and Methods}

Plant material and preparation of extracts and fractions

Dried O. sanctum (holy basil) leaves were purchased from Ramkrishna Mission, Kolkata, India, and botanically authenticated. Voucher specimens were deposited in the National Herbarium, Bangladesh. The leaves were dried at $40{ }^{\circ} \mathrm{C}$ and ground into a fine powder. The powder $(2 \mathrm{~kg})$ was extracted with $80 \%$ ethanol (10 l) in a stainless steel extraction tank for approximately 4 days at room temperature by changing ethanol daily. The combined extract was filtered and evaporated to dryness using a rotary evaporator. A membrane pump was used to evacuate the extract in order to remove the residual solvent. The extract was finally freeze dried $(275 \mathrm{~g})$ by using a Varian 801 LY-3-TT freeze-dryer (Varian, Lexington, MA, USA). The dry sample was stored at $4{ }^{\circ} \mathrm{C}$.

The ethanol extract $(100 \mathrm{~g})$ was subsequently partitioned between hexane $(3 \times 0.51)$ and water $(0.51)$. The hexane fraction was separated and evaporated to dryness to get hexane-soluble material $(19 \cdot 6 \mathrm{~g})$. The aqueous layer was further partitioned $(3 \times 0.5 \mathrm{l})$ using solvents and evaporated to dryness to get chloroform- $(16.9 \mathrm{~g})$, ethyl acetate- $(5 \cdot 5 \mathrm{~g})$ and butan-1-ol- $(7 \cdot 8 \mathrm{~g})$ soluble materials. The residual aqueous part was condensed by rotary evaporator and finally freeze dried. Figure 1 outlines the 
preparation of ethanol extraction and five partition fractions of dried leaves of $O$. sanctum.

Effects of $\mathrm{O}$. sanctum on insulin secretion from perfused pancreas

Long-Evans rats $(180-250 \mathrm{~g})$ were anaesthetized with sodium pentobarbital $(50 \mathrm{mg} / \mathrm{kg}$, i.p.) and the pancreas was isolated and perfused at $37^{\circ} \mathrm{C}$ according to the method of Giroix et al. (1983). Extract and fractions of O. sanctum were dissolved in Krebs-Ringer bicarbonate buffer (KRB; $118 \mathrm{mM} \mathrm{NaCl}, 4 \mathrm{mM} \mathrm{KCl}, 2.5 \mathrm{mM} \mathrm{CaCl}_{2}$, $1.2 \mathrm{mM} \mathrm{MgSO}_{4}, 1.2 \mathrm{mM} \mathrm{KH}_{2} \mathrm{PO}_{4}, 25 \mathrm{mM} \mathrm{NaHCO}$, $1.25 \mathrm{~g} / 1 \mathrm{BSA}$ and $40 \mathrm{~g} / 1$ dextran T70, $\mathrm{pH} 7 \cdot 4$ ) containing 2.8 or $11.1 \mathrm{mM}$ D-glucose. The perfusate was continuously gassed with a mixture of $\mathrm{O}_{2} / \mathrm{CO}_{2}$ (95:5). After the first 20-min equilibration period, the composition of the perfusate changed as indicated in Fig. 2 (see below). Effluent samples were stored at $-20{ }^{\circ} \mathrm{C}$ for insulin assay.

\section{Effects of $\mathrm{O}$. sanctum on insulin secretion from isolated islets}

Islets were isolated on the day of experimentation from the pancreas of Long-Evans rats $(180-250 \mathrm{~g})$ by collagenase digestion (Moskalewski 1969). Following preincubation for $40 \mathrm{~min}$ in $\mathrm{KRB}$ containing $3 \mathrm{mM}$ glucose, batches of $8-10$ islets were incubated for $1 \mathrm{~h}$ at $37^{\circ} \mathrm{C}$ in $400 \mu \mathrm{l}$ buffer containing 3 or $11.1 \mathrm{mM}$ glucose and with either extracts or fractions of $O$. sanctum (detailed in Table 1 , see below). Aliquots of supernatant were stored at $-20{ }^{\circ} \mathrm{C}$ for insulin assay.

Effects of $\mathrm{O}$. sanctum on insulin secretion and intracellular $\mathrm{Ca}^{2+}$ in clonal $\beta$-cells

Clonal BRIN-BD11 cells were used to evaluate the mechanism underlying the effects of $O$. sanctum on insulin secretion, including modulation of intracellular $\mathrm{Ca}^{2+}$. The origin and characteristics of this glucose-responsive rat cell line are described in detail elsewhere (McClenaghan et al. 1996). Cells were seeded into $24-w e l l$ plates $0.15 \times 10^{6}$ cells $/$ well and allowed to attach overnight. Following preincubation for $40 \mathrm{~min}$ in KRB supplemented with $1.1 \mathrm{mM}$ glucose, cells were incubated for $20 \mathrm{~min}$ at $37^{\circ} \mathrm{C}$ in the same buffer supplemented with glucose, $O$. sanctum extracts and other reagents as indicated in the figures. In selected experiments, the viability of cells exposed to various plant extracts was assessed. Aliquots were removed from each well and stored at $-20{ }^{\circ} \mathrm{C}$ for insulin assay. In further series of experiments, the effects of $O$. sanctum on intracellular $\mathrm{Ca}^{2+}\left(\left[\mathrm{Ca}^{2+}\right]_{\mathrm{i}}\right)$ were determined using BRIN-BD11 cell monolayers seeded onto 96-well black-walled, clear-bottomed microplates (Greiner). Cells were washed with KRB and loaded with FLEX calcium assay reagent (Molecular Devices,
Sunnyvale, CA, USA), for $10 \mathrm{~min}$ at $37^{\circ} \mathrm{C}$ (Miguel et al. 2004). Fluorometric data during subsequent exposure to plant extract and other test agents were acquired using the FLEXstation $^{\text {TM }}$ (Molecular Devices) at a wavelength of $525 \mathrm{~nm}$.

\section{Analysis}

For perfusion and islet studies, insulin was measured by ELISA using kits supplied by Crystal Chem (Downers Grove, IL, USA). In studies using BRIN-BD11 cells, insulin was measured by RIA (Flatt \& Bailey 1981). The protein content of islets was detemined using the detergent-compatible protein kit supplied by BioRad. Cell viability was evaluated by modified Neutral Red assay (Hunt et al. 1987).

\section{Statistical analysis}

Results are presented as means \pm S.D. for a given number of observations $(n)$. Data from each set of observations were compared using unpaired Student's unpaired $t$-test and Mann-Whitney $U$-test where appropriate (SPSS for Windows). One-way analysis of variance (ANOVA) was performed and comparisons with the control group made using Dunnett's test to preserve an overall error rate of $5 \%$. Differences were considered significant if $P<0 \cdot 05$.

\section{Results}

Effects of $\mathrm{O}$. sanctum on insulin secretion from perfused pancreas

Ethanol extract of $O$. sanctum caused a significant $(P<0 \cdot 001)$ biphasic increase in insulin release during 10 -min perfusion, with a peak 21 -fold increase above the basal level (Fig. 2A). Subsequent exposure for $5 \mathrm{~min}$ to $11 \mathrm{mM}$ glucose caused a steep elevation of insulin release from the basal level of $0 \cdot 05 \pm 0 \cdot 01 \mathrm{ng} / \mathrm{ml}$ to peak value of $1 \cdot 12 \pm 0.08 \mathrm{ng} / \mathrm{ml}(P<0 \cdot 001)$. When extract was reintroduced at $11 \mathrm{mM}$ glucose, there was a further protracted stimulation of insulin release $(P<0 \cdot 05)$, which reversed the falling insulin output observed in the continued presence of $11 \mathrm{mM}$ glucose alone. As shown in Fig. 2B, perfusion with aqueous, butanol and ethylacetate fractions significantly $(P<0 \cdot 001)$ increased in insulin release in an almost similar pattern (highest peak of insulin secretion: basal, $0.03 \pm 0.01 \mathrm{ng} / \mathrm{ml} ;$ aqueous fraction, $1.7 \pm 0.2 \mathrm{ng} / \mathrm{ml}$; butanol fraction; $1 \cdot 2 \pm 0.1 \mathrm{ng} / \mathrm{ml}$; ethylacetate fraction; $1 \cdot 4 \pm 0 \cdot 1 \mathrm{ng} / \mathrm{ml})$. These fractions stimulated further insulin release at $11 \cdot 1 \mathrm{mM}$ glucose (peak output: $1 \cdot 33 \pm 0 \cdot 1$ versus $1 \cdot 8 \pm 0 \cdot 1,1 \cdot 3 \pm 0 \cdot 1,1 \cdot 6 \pm 0 \cdot 1,1 \cdot 2 \pm 0 \cdot 1$ and $1 \cdot 5 \pm 0 \cdot 1 \mathrm{ng} / \mathrm{ml}$, respectively; $P<0 \cdot 05)$. Hexane and chloroform fractions showed less prominent effects on insulin 

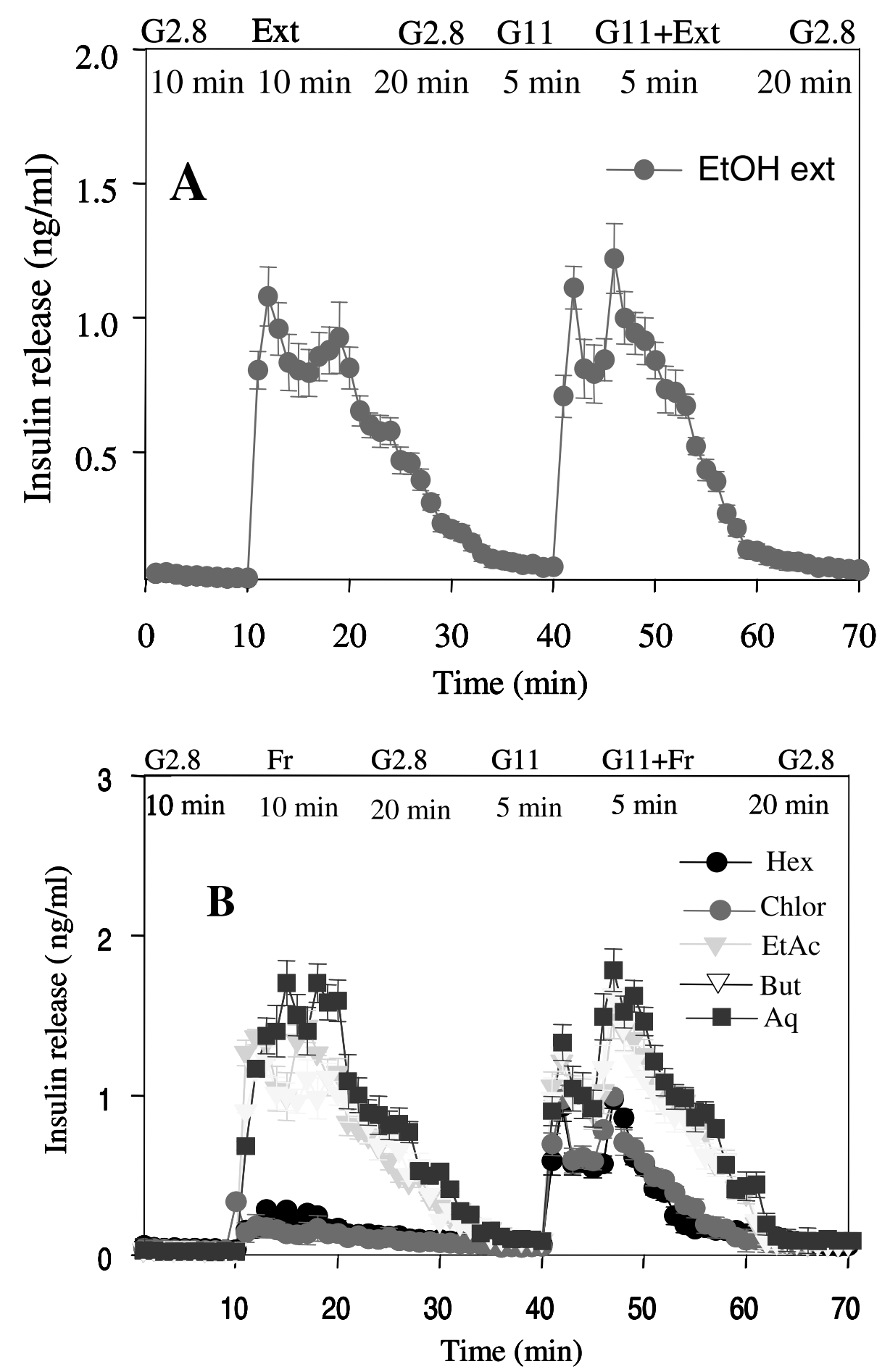

Figure 2 Effects of the (A) ethanol extract and (B) five partitioned fractions of $O$. sanctum on insulin release from perfused rat pancreas. Data are means \pm S.D. from four or five separate experiments. Pancreas was perfused with extract/fractions at a dose of $1 \mathrm{mg} / \mathrm{min}$. The glucose concentration was raised from the basal level of $2 \cdot 8 \mathrm{mM}$ to $11 \mathrm{mM}$. EtOH, ethanol; Ext, extract; $\mathrm{Fr}$, fraction; Gn, glucose plus concentration in $\mathrm{mM}$; Hex, hexane; Chlor, chloroform; EtAc, ethylacetate; But, butanol; Aq, aqueous. 
Table 1 Effects of the ethanol extract and five partition fractions of $O$. sanctum on insulin secretion from isolated rat islets

\begin{tabular}{|c|c|c|c|}
\hline & \multirow{2}{*}{$\begin{array}{l}\text { Yield from } \\
\text { starting materials } \\
(\mathrm{g} / \mathrm{kg})\end{array}$} & \multicolumn{2}{|c|}{ Insulin secretion ( $\mathrm{ng} / \mathrm{mg}$ islet protein) } \\
\hline & & $3 \mathrm{mM}$ Glucose & $11 \mathrm{mM}$ Glucose \\
\hline \multicolumn{4}{|l|}{ Group } \\
\hline Control $(n=6)$ & No extact/fraction & $2 \cdot 99(2 \cdot 65-4 \cdot 27)$ & $5 \cdot 41(4 \cdot 91-9 \cdot 27)$ \\
\hline Ethanol $(80 \%)$ extract $(n=6)$ & $137 \cdot 5$ & $4 \cdot 82(3 \cdot 85-6 \cdot 20)^{*}$ & $6 \cdot 23(4 \cdot 95-8 \cdot 49)^{*}$ \\
\hline Ethylacetate fraction $(n=7)$ & $7 \cdot 6$ & $5 \cdot 41(3 \cdot 2-8 \cdot 13)^{\star \star}$ & $6 \cdot 15(3 \cdot 41-11 \cdot 25)^{*}$ \\
\hline Butanol fraction $(n=6)$ & $10 \cdot 8$ & $5.96(4 \cdot 90-10 \cdot 32)^{* *}$ & $7 \cdot 68(5 \cdot 46-12 \cdot 29)^{*}$ \\
\hline Aqueous fraction $(n=6)$ & $66 \cdot 2$ & $4 \cdot 98(3 \cdot 36-9 \cdot 24)^{*}$ & $6 \cdot 49(3.46-8.69)^{*}$ \\
\hline Hexane fraction $(n=6)$ & $27 \cdot 0$ & $3 \cdot 08(2 \cdot 67-4.91)$ & $5 \cdot 49(4 \cdot 78-7 \cdot 58)$ \\
\hline Chloroform fraction $(n=6)$ & $23 \cdot 2$ & $3 \cdot 19(2 \cdot 42-5 \cdot 98)$ & $5 \cdot 46(4 \cdot 51-9 \cdot 12)$ \\
\hline
\end{tabular}

Isolated rat islets were incubated for $60 \mathrm{~min}$ with ethanol extract and partition fractions of $O$. sanctum $(30 \mu \mathrm{g} / \mathrm{ml})$ in the absence and presence of $11 \mathrm{mM}$ glucose. Data are presented as medians, with ranges in parentheses. Mann-Whitney $U$-test was used to evaluate statistical significance. ${ }^{*} P<0 \cdot 05, P<0 \cdot 01$ compared to control.

release from perfused pancreas, especially at the lower glucose concentration (Fig. 2B).

\section{Effects of $\mathrm{O}$. sanctum on insulin secretion from isolated islets}

Table 1 shows the effects of the ethanol extract and five partition fractions on insulin secretion from isolated rat islets in the presence of 3 and $11.1 \mathrm{mM}$ glucose. Ethanol extract and three partition fractions (ethyl acetate, butanol and aqueous) increased insulin release by $61-99 \%$ compared with the $3 \mathrm{mM}$ glucose control $(P<0 \cdot 05$ and $P<0.01$; Table 1). Increasing glucose concentration from 3 to $11.1 \mathrm{mM}$ caused a 2 -fold increase in insulin release. The ethanol extract and three fractions (ethyl acetate, butanol and aqueous) enhanced glucose-induced insulin secretion by $1 \cdot 2-1 \cdot 4$-fold when compared with the $11 \cdot 1 \mathrm{mM}$ glucose control $(P<0 \cdot 05)$. Hexane and chloroform fractions lacked significant effects on insulin release.

\section{Effects of $\mathrm{O}$. sanctum on insulin secretion from clonal $B R I N-B D 11$ cell line}

The effects of increasing concentrations $(8-5000 \mu \mathrm{g} / \mathrm{ml})$ of ethanol extract and five partition fractions of $O$. sanctum on insulin secretion from BRIN-BD11 cells are shown in Fig. 3. The ethanol extract evoked concentrationdependent 2-22-fold increases in insulin release compared with $5.6 \mathrm{mM}$ glucose alone $(P<0 \cdot 05-P<0 \cdot 001)$. Concentrations up to $200 \mu \mathrm{g} / \mathrm{ml}$ did not alter cellular viability but higher concentrations decreased viability by $15-20 \%$ (data not shown). Three fractions of $O$. sanctum (aqueous, butanol and ethyl acetate) stimulated insulin secretion in a concentration-dependent manner between 200 and $5000 \mu \mathrm{g} / \mathrm{ml}(P<0 \cdot 05-P<0 \cdot 001)$. Only at the higher concentration of $5000 \mu \mathrm{g} / \mathrm{ml}$ was cell viability decreased (aqueous, $\quad 87 \pm 15 \%, \quad P<0 \cdot 05 ; \quad$ butanol, $\quad 85 \pm 12 \%$, $P<0 \cdot 05$; ethylacetate, $78 \pm 13 \%, P<0 \cdot 01)$. Chloroform and hexane fractions increased insulin release $(P<0 \cdot 001)$ at $5000 \mu \mathrm{g} / \mathrm{ml}$, but this was associated with a significant reduction of cell viability (chloroform, $37 \pm 6 \cdot 0 \%$; hexane, $50 \pm 10 \%$; $P<0 \cdot 001)$.

Further studies used non-toxic concentrations to evaluate the possible mechanisms underlying the insulinsecretory actions of O. sanctum. As shown in Fig. 4, insulin release induced by $200 \mu \mathrm{g} / \mathrm{ml}$ ethanol extract $(P<0 \cdot 001)$ was potentiated by $16.7 \mathrm{mM}$ glucose $(P<0 \cdot 05)$, isobutylmethylxanthine (IBMX; $P<0 \cdot 001$ ) and tolbutamide $(P<0 \cdot 05)$. In contrast, the effects of $O$. sanctum extracts were inhibited by diazoxide $(P<0 \cdot 01)$ and verapamil $(P<0 \cdot 001)$. The ethanol extract also maintained its ability to enhance insulin secretion from cells depolarized with $30 \mathrm{mM} \mathrm{KCl}$ (Fig. 4). Similar effects were noted for aqueous, butanol and ethylacetate fractions in the presence of insulin secretagogues (glucose, IBMX, tolbutamide), inhibitors (diazoxide and verapamil) and depolarizing concentrations of $\mathrm{KCl}$ (Fig. 4). Removal of $\mathrm{Ca}^{2+}$ from the test buffer significantly reduced $(P<0.001)$ but did not totally abolish insulin release induced by ethanol extract and three partition fractions (aqueous, butanol and ethylacetate; $P<0 \cdot 001$, Fig. 5).

Effects of $\mathrm{O}$. sanctum on intracellular calcium in the clonal BRIN-BD11 cell line

Figure 6 shows the effects of the ethanol extract and three partition fractions (aqueous, butanol and ethylacetate) of O. sanctum on $\left[\mathrm{Ca}^{2+}\right]_{\mathrm{i}}$. Exposure to the ethanol extract and both the aqueous and butanol fractions produced a prompt increase of $\left(\left[\mathrm{Ca}^{2+}\right]_{i}\right)$. This was largely reduced by the addition of the blocker of voltage-dependent calcium channels, verapamil $(50 \mu \mathrm{M})$. Similar effects were observed with the ethyl acetate fraction but effects were much less prominent (Fig. 6). 

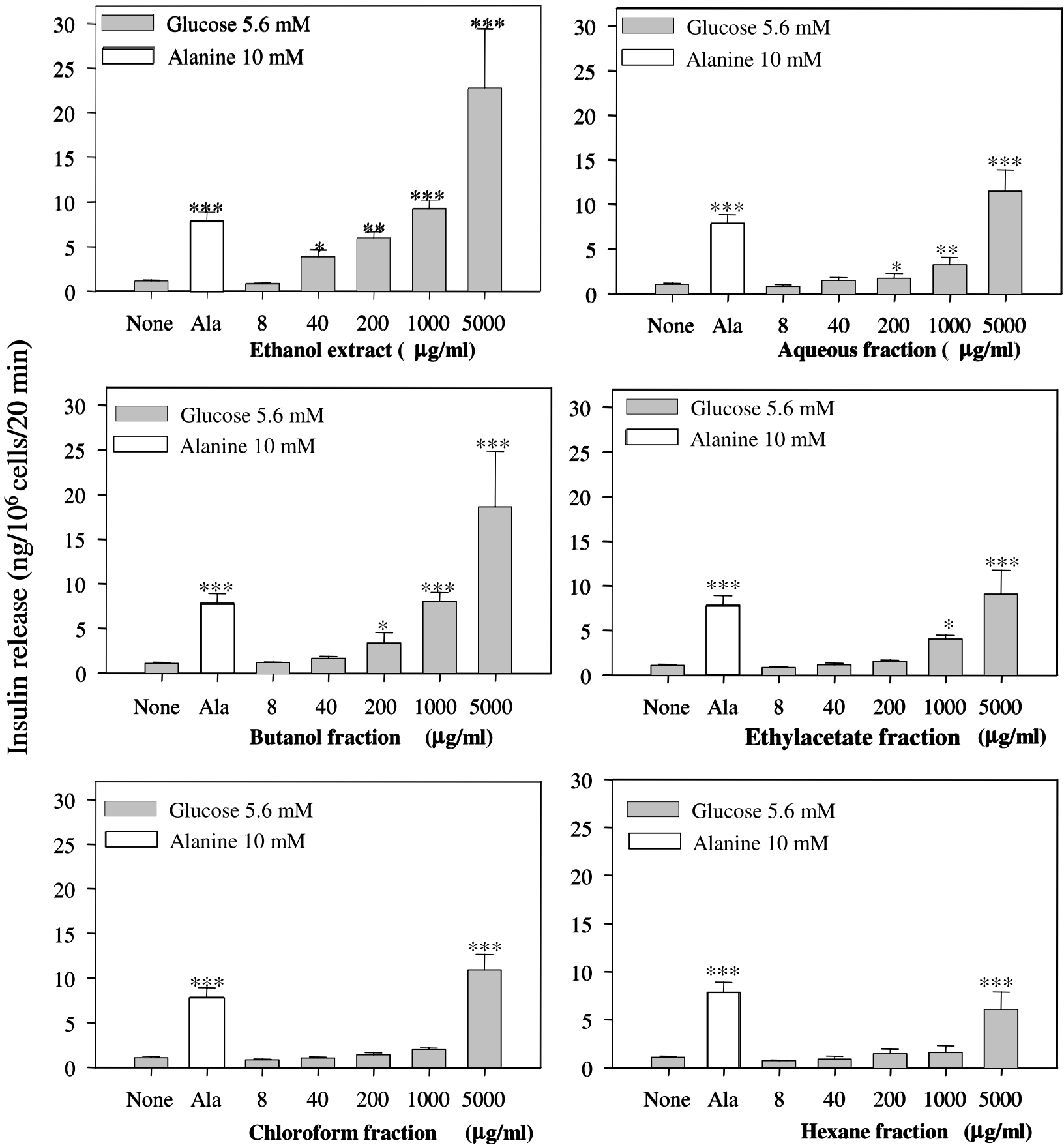

Figure 3 Effects of different concentrations of the ethanol extract and five partition fractions of $O$. sanctum on insulin release from BRIN-BD11 cells. Results are means \pm S.D. from eight separate observations. ${ }^{*} P<0 \cdot 05,{ }^{*} P<0 \cdot 01,{ }^{*} * * P<0 \cdot 001$ compared with $5 \cdot 6 \mathrm{mM}$ glucose. One-way ANOVA was performed and pairwise comparisons with the control $(5.6 \mathrm{mM}$ glucose) group used Dunnett's test to preserve an overall error rate of $5 \%$.

\section{Discussion}

The leaves of $O$. sanctum have been claimed to possess antidiabetic properties by the traditional healers. There exist some scientific reports (Agarwal et al. 1996, Rai 1997. Chattopadhyay 1999) consistent with the antihyperglycaemic activity of this plant, but its mechanism of action has not yet been elucidated. This study has 

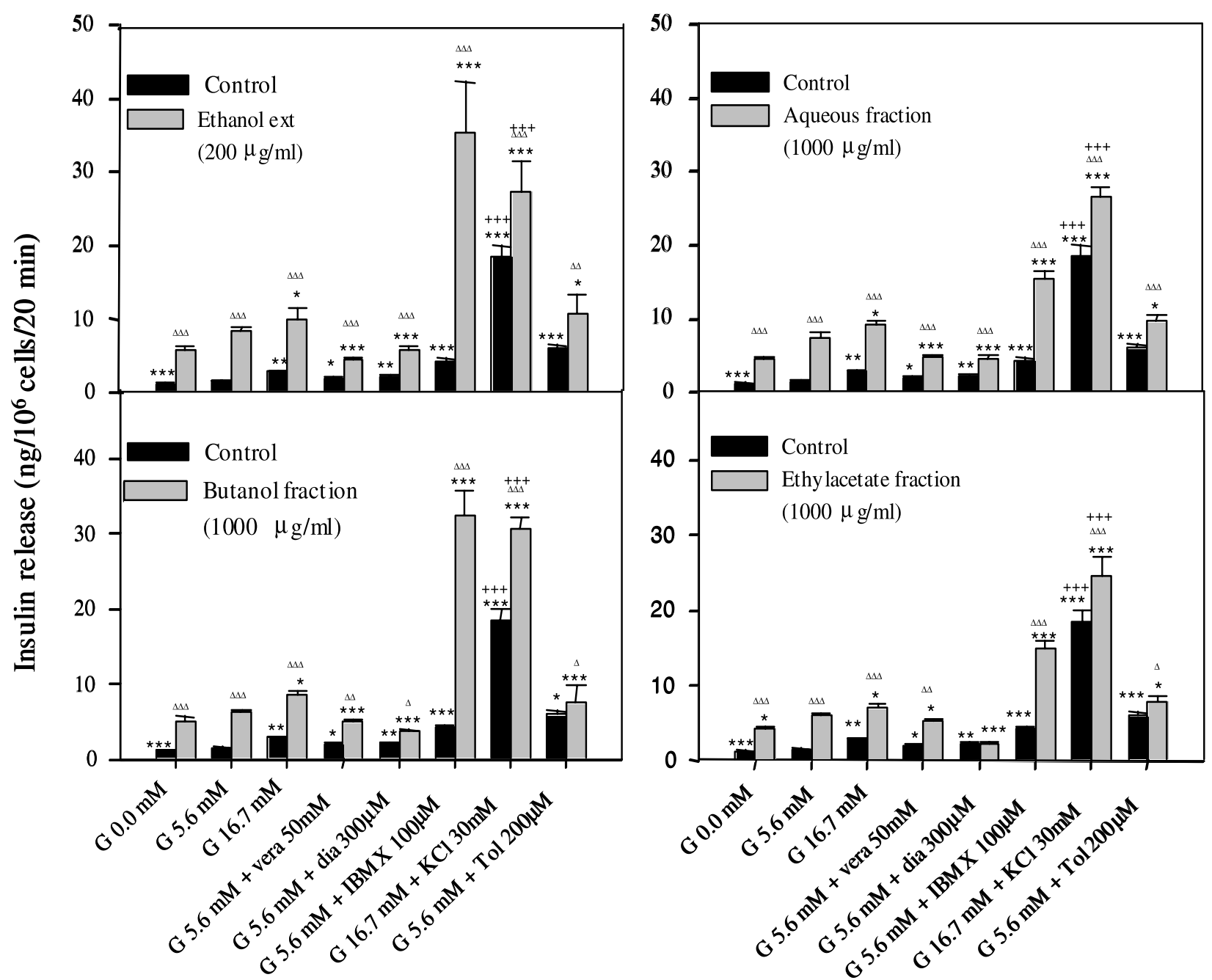

Figure 4 Effects of the ethanol extract and five partition fractions of $O$. sanctum on insulin release from BRIN-BD11 cells in the presence of established stimulants and inhibitors of insulin secretion. Results are means \pm S.D. from eight separate observations. ${ }^{*} P<0 \cdot 05,{ }^{*} * P<0 \cdot 01$, ${ }^{* * *} P<0.001$ compared with $5.6 \mathrm{mM}$ glucose in the presence or absence of plant extract. $\triangle P<0 \cdot 05, \triangle \triangle P<0 \cdot 01, \triangle \triangle \triangle P<0 \cdot 001$ compared with the respective incubations in the absence of plant extract. ${ }^{++} P<0.001$ compared with $16.7 \mathrm{mM}$ glucose in the presence or absence of plant extract. One-way ANOVA was performed and pairwise comparisons with the control ( $5 \cdot 6 \mathrm{mM}$ glucose) used Dunnett's test to preserve an overall error rate of 5\%. dia, diazoxide; G, glucose; Tol, tolbutamide; vera, Verapamil.

examined the insulinotropic effects of $O$. sanctum using the perfused rat pancreas, isolated rat islets and the clonal rat BRIN-BD11 cell line.

Prominent insulin-secretory effects of the ethanol extract and three partition (ethylacetate, butanol and aqueous) fractions were noted in the perfused rat pancreas. Similar effects were found in acute insulinrelease studies using isolated rat islets and the clonal rat cell line BRIN-BD11. In these experiments, prominent insulinotropic effects were observed in the more polar compared with the hexane and chloroform fractions. Ethanol extract and the aqueous, butanol and ethylacetate fractions showed dose-dependent stimulatory effects on insulin secretion in BRIN-BD11 cells. Hexane and chloroform fractions were effective at higher concentrations, but this was associated with toxic effects on cell viability.

Non-toxic concentrations of $O$. sanctum extract and partition fractions were used to study mechanisms underlying stimulation of insulin secretion. The extract stimulated basal insulin secretion with an action enhanced by increasing the glucose concentration over the range $2 \cdot 8-16 \cdot 7 \mathrm{mM}$. The effects of tolbutamide, and a membrane-depolarizing concentration of $\mathrm{KCl}(30 \mathrm{mM})$, were tested in the absence and presence of the extract. This sulphonylurea is known to act by closing $\mathrm{K}_{\text {ATP }}$ channels, depolarizing the plasma membrane and stimulating $\mathrm{Ca}^{2+}$ entry by activation of voltage-dependent 


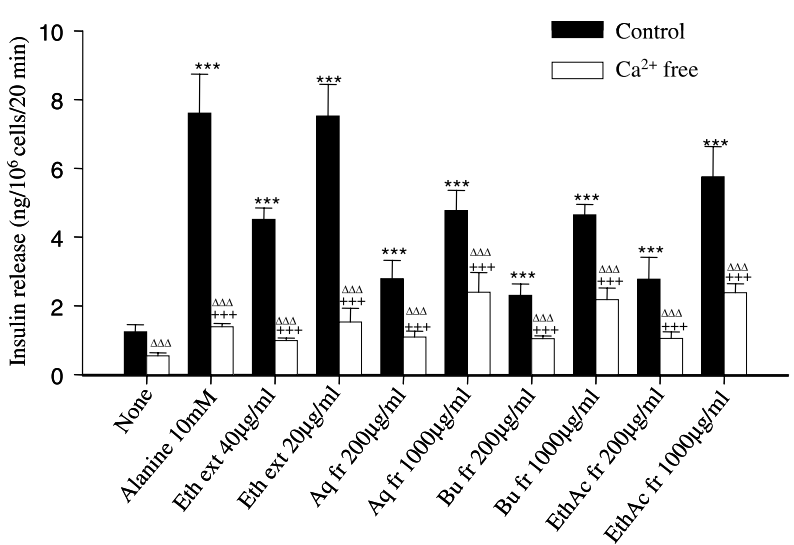

Figure 5 Effects of various concentrations of the ethanol extract and three partition fractions of $O$. sanctum on insulin release from BRIN-BD11 cells in the presence and absence of $\mathrm{Ca}^{2+}$. Results are means \pm S.D. from eight separate observations. ${ }^{* * *} P<0 \cdot 001$ compared with $5.6 \mathrm{mM}$ glucose in the presence of $\mathrm{Ca}^{2+}$. $\triangle \triangle \triangle P<0.001$ compared with the respective concentration in the presence of $\mathrm{Ca}^{2+} .{ }^{+++} P<0.001$ compared with $5.6 \mathrm{mM}$ glucose in the absence of $\mathrm{Ca}^{2+}$. One-way ANOVA was performed and pairwise comparisons with the control $(5.6 \mathrm{mM}$ glucose) group used Dunnett's test to preserve an overall error rate of $5 \%$. Eth ext, ethanol extract; $\mathrm{Aq} \mathrm{fr}$, aqueous fraction; $\mathrm{Bu} \mathrm{fr}$, butanol fraction; EthAc fr, ethylacetate fraction.
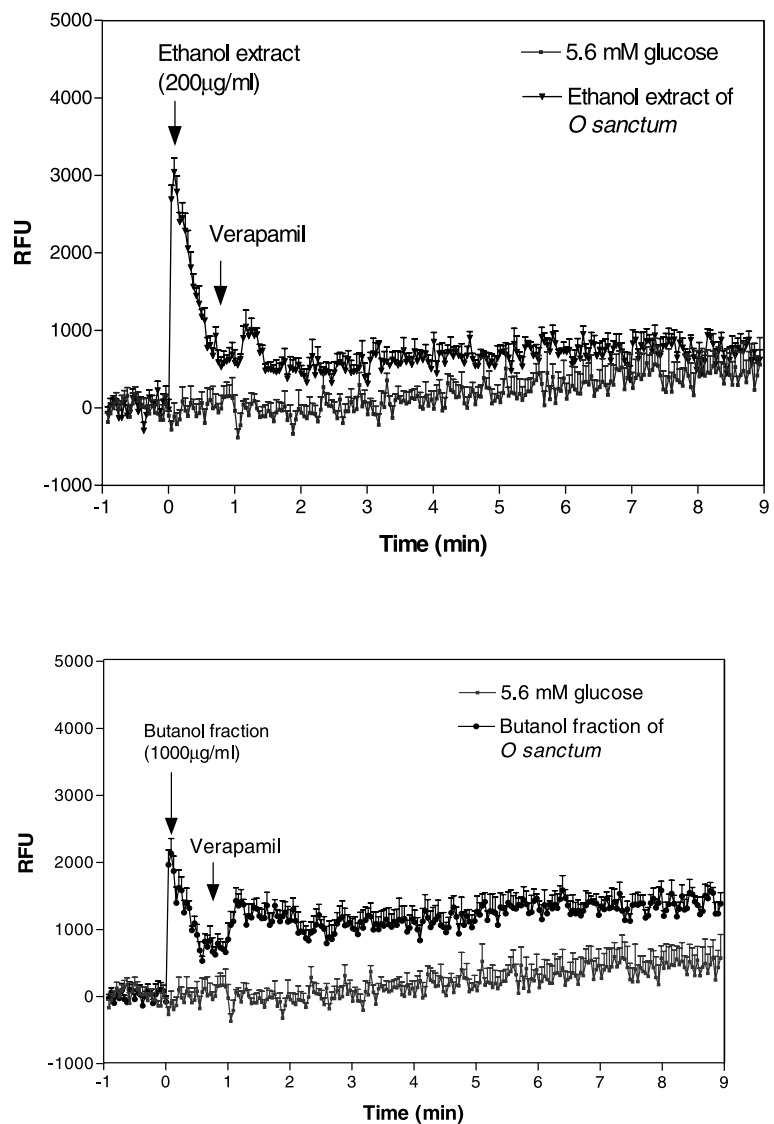

calcium channels (Boyd 1988). The extract enhanced insulin secretion under both conditions, indicating that the extract acts by mechanisms in addition to effects on $\mathrm{K}_{\text {ATP }}$ and other ion channels. Augmentation of insulin secretion in these depolarized conditions suggests possible intracellular actions such as stimulation of adenylate cyclase/cAMP or the phosphatidylinositol pathway, or direct effects on exocytosis.

Additional experiments were performed to assess the effects of extract on insulin secretion in the presence of other modulators, known to affect secondary-messenger pathways in $\beta$-cells. The effects of IBMX, an inhibitor of cAMP phosphodiesterase (Sharp 1979), were markedly increased by $O$. sanctum. Interestingly, the traditional use of $O$. sanctum for treatment of asthma in India has been scientifically supported (Singh et al. 1980, Sharma 1983, Palit et al. 1983, Warier 1995b). The anti-asthmatic actions have been attributed to elevation of cAMP in bronchial smooth muscle cells, promoting airway relaxation and blocking replication of smooth muscle cells (Tomlinson et al. 1995).

Involvement of ion channels in the stimulatory action of O. sanctum was also evident in $\beta$-cells. Diazoxide, a $\mathrm{K}_{\mathrm{ATP}}$-channel opener (Henquin et al. 1992), inhibited the
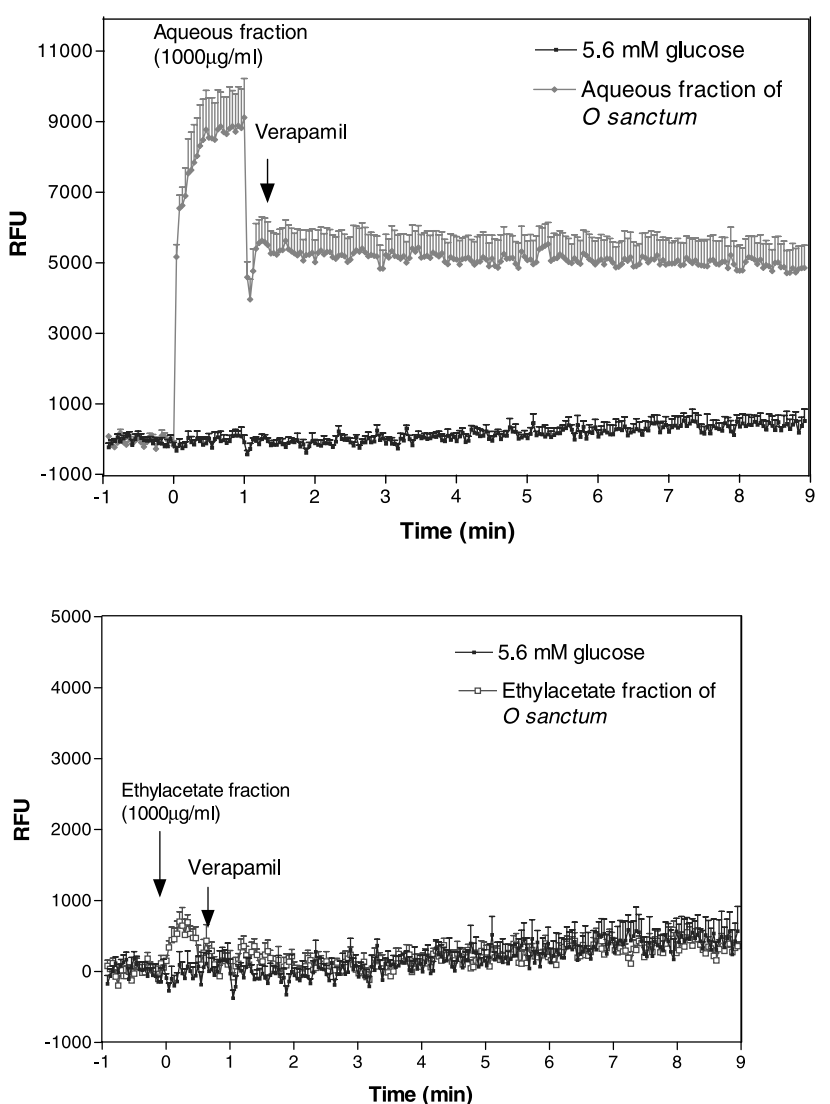

Figure 6 Effects of the ethanol extract and three partition fractions of $O$. sanctum on $\left[\mathrm{Ca}^{2+}\right]_{\mathrm{i}}$ in BRIN-BD11 cells in the absence and presence of verapamil. Each data point represents the mean \pm s.D. from six separate observations. RFU, relative fluorescence units. 
insulin-releasing effects of the extract, suggesting that closure of $\mathrm{K}_{\mathrm{ATP}}$ channels participates in the overall mechanism of action of $O$. sanctum. This is supported by observations with verapamil, a voltage-dependent $\mathrm{Ca}^{2+}$ channel blocker (Weinhaus et al. 1995) that abolished the insulin-releasing effects of the extract. Similar dependence on extracellular $\mathrm{Ca}^{2+}$ was evident from experiments testing the effects of $\mathrm{Ca}^{2+}$-free buffer. The omission of $\mathrm{Ca}^{2+}$ did not completely abolish the insulin-secretory effects, suggesting that the extract can induce mobilization of intracellular $\mathrm{Ca}^{2+}$ as well as promoting $\mathrm{Ca}^{2+}$ entry. This conclusion was well supported by direct observation of intracellular $\mathrm{Ca}^{2+}$ in BRIN-BD11 cells. The extract had a rapid and prominent stimulatory effect on $\left[\mathrm{Ca}^{2+}\right]_{\mathrm{i}}$ which was inhibited but not abolished by verapamil.

Interestingly, each of the partition (aqueous, butanol, ethylacetate) fractions of $O$. sanctum exerted broadly similar effects on insulin secretion to the ethanol extract, including responses to insulinotropic antagonists (diazoxide, verapamil), agonists (tolbutamide, IBMX), depolarizing conditions ( $30 \mathrm{mM} \mathrm{KCl}$ plus $16.7 \mathrm{mM}$ glucose) and $\mathrm{Ca}^{2+}$ depletion, and also on $\left[\mathrm{Ca}^{2+}\right]_{\mathrm{i}}$. This reveals that the ethanol extract and these fractions contain active molecules that exert effects on the $\beta$-cells via similar mechanisms. Constituents of $O$. sanctum extracted by these polar solvents include polysaccharides, glycosides, amino acids, flavenoids and terpinoids (Platel \& Srinivasan 2000). Such activity was lost in the hexane and chloroform partition fractions.

In conclusion, this study has shown that $O$. sanctum leaf extracts exert prominent stimulatory effects on insulin secretion from the $\beta$-cells via physiological pathways. In vivo studies also indicate that the ethanol extract decreased blood glucose and increased plasma insulin in type 2 diabetic rats (Hannan et al. 2003). Future work directed at the purification and characterization of active components may reveal new agents for diabetes therapy.

\section{Acknowledgement}

These studies were supported in part by University of Ulster Research Strategy Funding. The authors declare that there is no conflict of interest that would prejudice the impartiality of this scientific work.

\section{References}

Agarwal P, Rai V \& Singh RB 1996 Randomized placebo-controlled, single blind trial of holy basil leaves in patients with non-insulin dependent diabetes mellitus. International Journal of Clinical Pharmacology \& Therapy 34 406-409.

Ajgaonkar SS 1979 Herbal drugs in the treatment of diabetes. International Diabetes Federation Bulletin 24 10-17.

Alarcon-Aguilara FJ, Roman-Ramos R, Perez-Gutierrez S, Aguilar-Contreras A, Contreras-Weber CC \& Flores-Saenz JL 1998 Study of the anti-hyperglycemic effect of plants used as antidiabetics. Journal of Ethnopharmacology 61 101-110.
Bhargava KP \& Singh N 1981 Anti-stress activity of O sanctum. Indian Journal of Medical Research 73 443-451.

Boyd III AE 1988 Sulfonylurea receptors, ion channels, and fruit flies. Diabetes 37 847-850.

Chattopadhyay RR 1993 Hypoglycemic effect of O sanctum leaf extract in normal and streptozotocin diabetic rats. Indian Journal of Experimental Biology 31 891-893.

Chattopadhyay RR 1999 A comparative evaluation of some blood sugar lowering agents of plant origin. Journal of Ethnopharmacology 67 367-372.

Chopra RN, Nayer SL \& Chopra IC 1956 Glossary of Indian Medicinal Plants. New Delhi, India: CSIR.

Dastur JF 1962 Medicinal Plants of India and Pakistan. Bombay, India: DB Taraporevala Sons \& Co.

Dhar ML, Dhar MM, Dhawan BN, Mehrotra BN \& Roy C 1968 Screening of Indian plants for biological activity, Part I. Indian Journal of Experimental Biology 6 232-247.

Evans WC 1996 Trease and Evan's Pharmacognosy. London, UK: WB Saunders.

Farjou IB, Al-Ani M \& Guirgues SY 1987 Lowering of blood glucose in diabetes rabbits by Artemisia extract. Journal of the Faculty of Medicine, Baghdad 92 137-141.

Farnsworth NR 1980 The development of pharmacological and chemical research for application of traditional medicine in developing countries. Journal of Ethnopharmacology 2 173-181.

Flatt PR \& Bailey CJ 1981 Abnormal plasma glucose and insulin responses in heterozygous lean $(o b /+)$ mice. Diabetologia 20 573-577.

Giroix MH, Portha B, Kergoat M, Bailbe D \& Picon L 1983 Glucose insensitivity and amino-acid hypersensitivity of insulin release in rats with non-insulin-dependent diabetes: a study with the perfused pancreas. Diabetes 32 445-451.

Hannan JMA, Rokeya B, Khaleque J, Mala MA, Moshihuzzaman M, Nahar N, Azad Khan AK \& Ali L 2003 Hypoglycemic, hypolipidemic and hyperinsulinemic effects of a plant extract PE 026 leaves in Long-evans rats. Diabetes Metabolism 29270.

Henquin JC, Debuyser A, Drews G \& Plant TD 1992 Regulation of $\mathrm{K}^{+}$permeability and membrane potential in insulin-secretory cells In Nutrient Regulation of Insulin Secretion, pp 173-192. Ed PR Flatt. London, UK: Porland.

Hunt SM, Chrznowska C, Barnett CR, Brand HN \& Fawell JK 1987 A comparison of in vitro cytotoxicity assays and their application to water samples. Alternatives to Laboratory Animals 15 20-29.

Joglekar GV, Chaudhary NY \& Aiman R 1959 Effect of indigenous plant extracts on glucose-absorption in mice. Indian Journal of Physiology and Pharmacology 3 76-77.

Jouard H, Eddouks M, Lacaille-Dubois MA \& Lyoussi B 2000 Hypoglycemic effect of the water extract of Spergularia purpurea in normal and streptozotocin-induced diabetis rats. Journal of Ethnopharmacology 71 169-177.

Joy KL \& Kuttan R 1999 Antidiabetic activity of Picrorrhiza kurroa extract. Journal of Ethnopharmacology 167 143-148.

Karawya SM, Abdel Wahab SM, El-Olemy MM \& Farag M 1984 Diphenylamine, an antihyperglycemic agent from onion and tea. Journal of Natural Products 47 775-780.

Kirtikar K \& Basu B 1993 In Indian Medicinal Plants, pp 3-6. New Delhi, India: Periodical Expert Book Agency.

McClenaghan NH, Barnett CR, Ah-Sing E, Abdel-Wahab YHA, O'Harte FPM, Yoon T-W, Swanston-Flatt SK \& Flatt PR 1996 Characterization of a novel glucose-responsive insulin-secreting cell line, BRIN-BD11, produced by electrofusion. Diabetes 45 1132-1140.

Miguel JC, Patterson S, Abdel-Wahab YHA, Mathias PC \& Flatt PR 2004 Time-correlation betweem mewmbrane depolarization and intracellular calcium in insulin secretin BRIN-BD11 cells: studies using FLIPR. Cell Calcium 36 43-50. 
Moskalewski S 1969 Studies the culture and transplantation of isolated islets of langerhans of the guinea pig. Proceedings of the Koninklikjkc Nederlande Akademie van Wetenschappen 72 157-171.

Palit G, Singh SP, Singh N, Kohli \& Bhargava KP 1983 An experimental evaluation of anti-asthmatic plant drugs from the ancient Ayurvedic medicine. Aspects Allergy Immunol 1636.

Platel K \& Srinivasan K 2000 Influence of dietary spices and their active principles on pancreatic digestive enzymes in albino rats. Nahrung 44 2-46.

Pugazhenthi S \& Murthy PS 1996 Purification of three orally hypoglycaemic compounds KAKRA, 1b, III a1, and III b1 from the unripe fruits of Momordica charantia Linn. (bitter gourd). Indian Journal of Clinical Biochemistry 11 115-119.

Rai V 1997 Effect of Tulasi (O sanctum) leaf powder supplementation on blood sugar levels, serum lipids and tissue lipids in diabetic rats. Journal of Ethnopharmacology 50 9-16.

Rajashekharan S \& Tuli SN 1976 Vijaysar (Pterocarpus marsupium) in the treatment of Madhumeha (diabetes mellitus) - a clinical trial. Journal of Research in Indian Medicine, Yoga and Homeopathy 9 76-78.

Rang HP \& Dale MM 1991 In The Endocrine System Pharmacology, pp 504-508. Harlow, UK: Longman Group Ltd.

Sharma G 1983 Antiasthmatic efficacy of O sanctum. Sachitra Ayurved 35 665-668.

Sharp GWG 1979 The adenylate cyclase-cyclic AMP system in islets of Langerhans and its role in the control of insulin release. Diabetologia 16 287-297.

Singh N, Nath R \& Gupta ML 1980 An experimental evaluation of anti-asthmatic potential of Inula racemosa. Quarterly Journal of Crude Drug Research 18 86-96.

Singh N, Mishra N \& Srivastava AK 1991a Effect of antistress plants on biochemical changes during stress reactions. Indian Journal of Pharmacology 23 137-142.

Singh N, Verma P \& Mishra N $1991 b$ A comparative evaluation of some antistress agents of plant origin. Indian Journal of Pharmacology 23 99-103.

Swanston-Flatt, SK, Day C, Flatt PR \& Bailey CJ 1991a Evaluation of the antihyperglycaemic properties of traditional plant treatment for diabetes. In Frontiers in Diabetes Research: Lessons from Animal
Diabetes, pp 286-293. Ed E Shafrir. London, UK: Smith-Gordon and Company.

Swanston-Flatt, SK, Flatt, PR, Day C \& Bailey CJ $1991 b$ Traditional dietary adjuncts for the treatment of diabetes mellitus. Proceedings of the Nutrition Society 50 641-651.

Tomlinson PR, Wilson J W \& Stewart A G 1995 Salbutamol inhibits the proliferation of human airway smooth muscle cells grown in culture: relationship to elevated cAMP levels. Biochemical Pharmacology 49 1809-1819.

Vats V, Grover JK \& Rathi SS 2002 Evaluation of antihyperglycemic and hypoglycemic effect of $T$ foenumgraecum, $O$ sanctum and $P$ marsupium in normal and alloxanized diabetic rats. Journal of Ethnopharmacology 79 95-100.

Wagner H \& Winterhoff H 1994 Plant adaptogens. Phytomedicine 1 63-76.

Warier PK 1995a Eugenia jambolana Linn. In Indian Medicinal Plants, pp 48-51. Eds PK Warrier, VPK Nambiar \& C Ramankutty. Madras, India: Orient Longman.

Warier PK 1995b O basilicum Linn. In Indian Medicinal Plants, pp 160-163. Eds PK Warrier, VPK Nambiar \& C Ramankutty. Madras, India: Orient Longman.

Weinhaus AJ, Poronnik P, Cook DI \& Tuch BE 1995 Insulin secretagogues, but not glucose, stimulate an increase in $\left[\mathrm{Ca}^{2+}\right]$ in the foetal rat beta cell. Diabetes 44 118-124.

World Health Organization 1978 Resolution: Drug Policies and Management: Medicinal Plants, pp 31-33. Geneva, Switzerland: World Health Organization.

Zawalich WS \& Zawalich KC 1988 Induction of memory in rat pancreatic islets by tolbutamide: dependence on ambient glucose level, calcium, and phosphoinositide hydrolysis. Diabetes $37816-823$.

Received in final form 19 December 2005

Accepted 6 January 2006

Made available online as an Accepted Preprint

19 January 2006 